\title{
An Overview Of Performance Measurement METHODS IN SMES
}

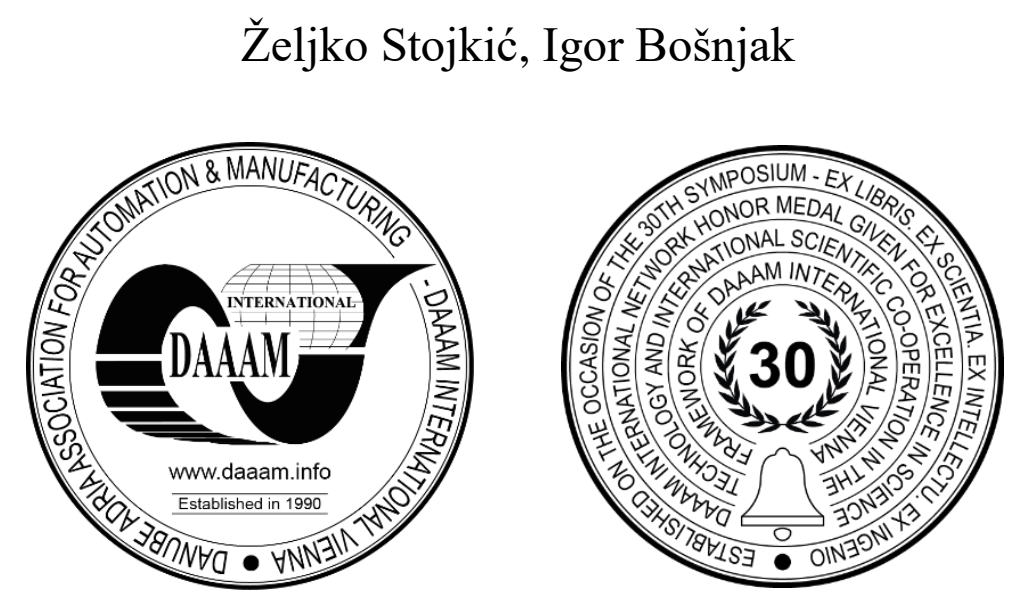

This Publication has to be referred as: Stojkic, Z[eljko] \& Bosnjak, I[gor] (2019). An Overview of Performance Measurement Methods in SMEs, Proceedings of the 30th DAAAM International Symposium, pp.0518-0524, B. Katalinic (Ed.), Published by DAAAM International, ISBN 978-3-902734-22-8, ISSN 1726-9679, Vienna, Austria

DOI: $10.2507 / 30$ th.daaam.proceedings.070

\begin{abstract}
Enterprises search for competitive advantages that leads them to improve their performance. The importance of performance measurement has gained increasing recognition in recent years. Companies have realized the need to effectively measure and monitor the enterprise's performance. Small and medium-sized enterprises (SMEs) have become increasingly important in national and international markets because they contribute to the development of local and national economies. SMEs often face serious challenges when competing with multinational companies. Large corporations have the financial, human capital and expertise to procure and implement complex performance measurement systems and ensure their relevance to the company's short- and long-term goals, Inclusive and effective performance measurement systems are essential for gaining competitive advantage and continuously adapting to the dynamic environment in which SMEs operate. Aim of this paper is to give an overview of the performance measurement methods in SMEs. Based on current research project of authors, it is necessary to recommend a methodology for performance measurement, depending on the research requirements.
\end{abstract}

Keywords: Performance measurement; Organisational performance; Small and medium-sized enterprises

\section{Introduction}

Each organisation is unique with regard to its products or services, customers, employees, experience, strategy, values, the result of previous decisions, etc. These characteristics and their evolution over time can play an important role in the success of implementing new improvement initiatives and are usually a consequence of the organisation's quality maturity level [1].

In the era of globalization, knowledge and information are significant factors of business success. Firms have to be flexible and capable to cope with uncertain market conditions and fierce competition by creating suitable business strategies. In order to do so, they need to be aware of their business situation, i.e. their business performance [2]. They can be used to monitor, control, communicate strategy, ensure that better decisions are made and consequently take actions, and check whether initiatives are proceeding according to plan [1]. 
In 2018, SME's represented $99.8 \%$ of all enterprises in the EU member states, and participated with $66.4 \%$ in total employment [3]. According to [4], these firms are "the backbone of the private sector all over the world." SMEs can have a clear impact on all national economies, generating wealth and contributing to economic development not only by generating jobs but also by supporting socioeconomic policies that lead to sustainable development [5], [6]. Literature has shown that most of the performance measurement systems employed by large corporations are unsuitable for SMEs as their operating environment is characteristically less complex and less resourced than large corporations [6], [7], [8], [9]. Thus, the need for a structured system for the purpose of decision-making provides the background for the adoption of a performance measurement system in SMEs [10].

Aim of this study is to investigate the methods for SME performance measurement. This paper represents a part of research project where the aim is to see how concepts of lean manufacturing and digitalisation impact on SME performances (Figure 1). Focus in this study is to see which methods/metrics are best suitable for the mentioned research project considering specific research conditions (country where the research project will be validated, availability of the data, size of target group, etc.). Paper contributes to this research area by demonstrating what are the most common methods for measuring firm performance and giving a suggestion for the given research conditions.

The remainder of the paper is structured as follows. Section 2 presents the literature review. Theoretical background of applied techniques is provided in Section 3. Section 4 presents and discusses the results.

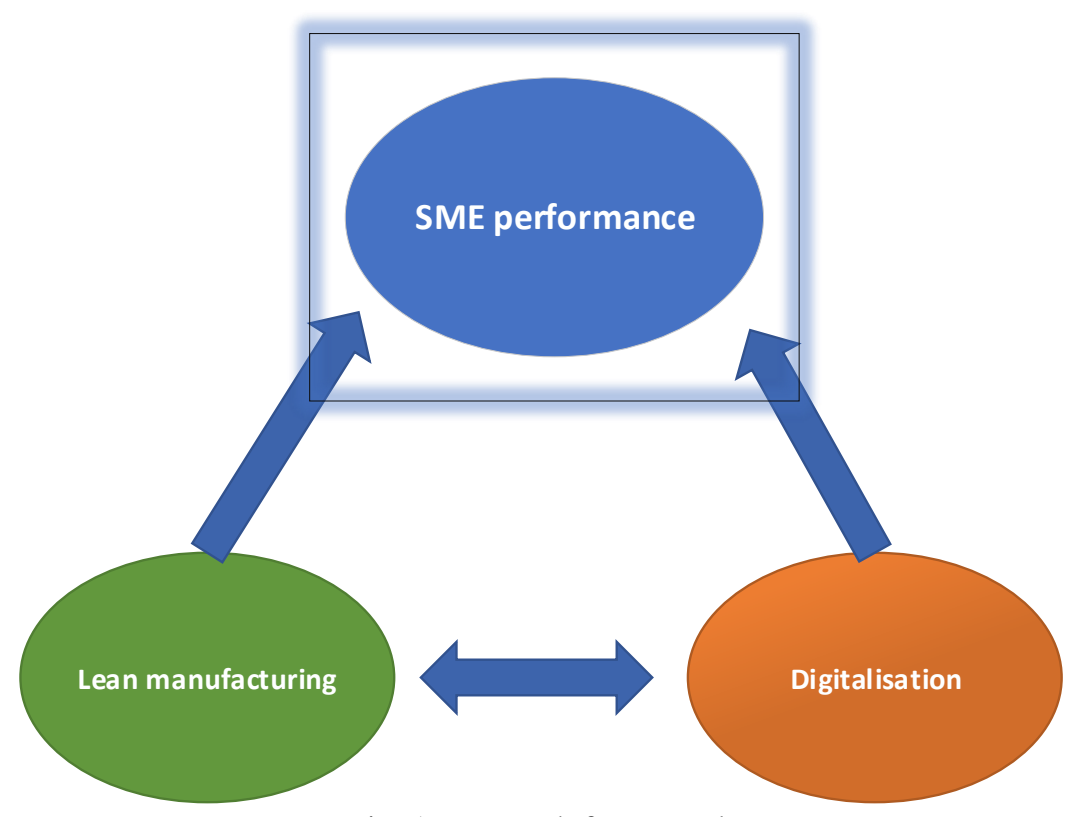

Fig. 1. Research framework

\section{Literature review}

Small and medium-sized enterprises (SMEs) are non-subsidiary, independent companies which employ less than a given number of employees. This number varies in different countries. The most frequent upper limit designating a SMEs is 250 employees, as in the European Union and Turkey. However, some countries set the limit at 200 employees, while the United States considers SMEs to include companies with less than 500 employees [4]. According to [11], SME definition takes into account the following three criteria:

- $\quad$ staff headcount

- annual turnover

- annual balance sheet total.

The category of micro, small and medium-sized enterprises consists of enterprises which:

- $\quad$ employ fewer than 250 persons; and

- $\quad$ have either an annual turnover not exceeding EUR 50 million or an annual balance sheet total not exceeding EUR 43 million.

In the 1980s, performance is defined as the extent to which an organization, as a social system, could consider both its means and ends [12], [13]. This definition is in line with the earlier one suggested by Georgopoulos and Tannenbaum [13], [14]. Cherrington [15] defined organizational performance as a concept of success or effectiveness of an organization, and as an indication of the organizational manner that it is performing effectively to achieve its objectives successfully. Laitinen [16] defines performance as the ability of the measurement object to generate outputs which can be measured by predetermined characteristics relative to predetermined goals. According to [17], performance can be defined as the ability of the measurement object to achieve results in relation to goals. Performance can refer to actual results/outputs of certain activities, how an activity is carried out, or an ability to achieve results [17]. 
Performance can also be defined through the dimensions that performance can be measured in. These dimensions include, for example finances [9], effectiveness [18], efficiency [18], profitability [18], productivity [18], [19], quality [9, 18, 19], time [8], [18], flexibility [8], [18], quality of working life/ human resources [8], [17], customer satisfaction [9] and innovation [18]. According to [20] there are two basic types of performance measure in any organisation, those that are related to results (competitiveness, financial performance), and those that focus on the determinants of the results (quality, flexibility, resource utilisation, and innovation). In addition, there are various performance measurement frameworks that are divided into perspectives that organisational performance can be measured in [21], [22]. The strength of a framework lies in the way how it takes into account different areas of performance: financial and non-financial performance, as well as internal and external performance [20]. A firm's performance is divided into two main areas: operational performance and financial performance. Financial performance is related to the results (profitability etc.) and operational performance to the determinants of the results (productivity, quality etc.). Financial performance can be measured via cost-based measures, but when measuring operational performance, both cost-based and non-cost measures can be utilised [16]. For instance, Liang, You and Liu [23] and Santos and Brito [24] identified that performance of the company/enterprise has two types:

- Financial performance;

- Strategic performance (it is important to mention that Santos and Brito [24] preferred naming this type „strategic performance“ instead of original „operational performance“).

These types could be represented by competitive aspects (dimensions of performance):

- profitability,

- growth,

- market value,

- customer satisfaction,

- employee's satisfaction,

- environmental performance and

- social performance.

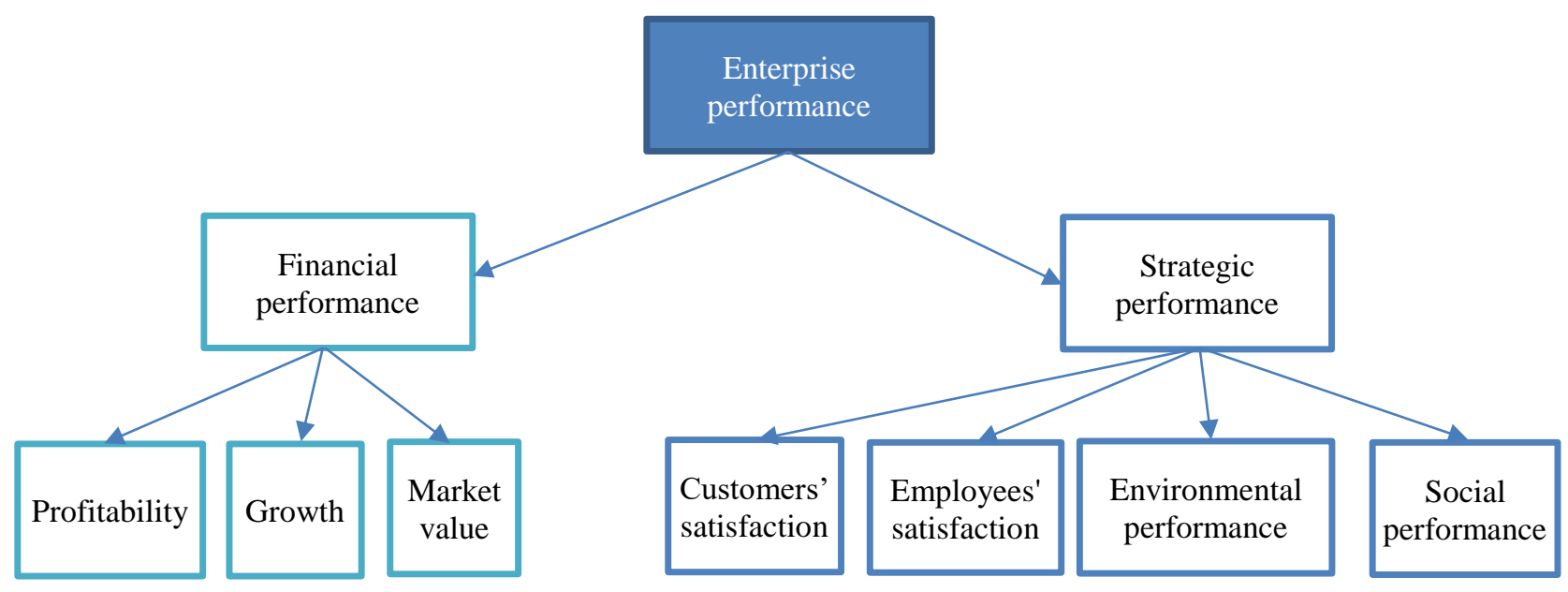

Fig. 2. Dimensions of performance [24], [25]

A necessary condition to achieve high performance standards is being able to effectively measure and monitor company's performance. In fact, the truthfulness of some famous sayings like "What gets measure gets attention" or "What you measure is what you get" is widely recognized both among academics and practitioners [26], [21], [7]. According to [22], "A Performance Measurement System is the set of metrics used to quantify the efficiency and effectiveness of past actions" and "it enables informed decisions to be made and actions to be taken because it quantifies the efficiency and effectiveness of past actions through the acquisition, collation, sorting, analysis and interpretation of appropriate data". Furthermore, they highlight that a PMS can be examined at three different levels: the individual measures of performance; the performance measurement system as a whole; the relationship between the PMS and the environment within which it operates [7]. Based on a plethora of academic writing on performance measurement, the following characteristics of a performance measurement system are deduced [10], [27], [7], [28], [8], [22]:

1. Well-articulated and purposeful in nature - The measurement processes should be unambiguous about what is being measured and be relevant to the SME's business.

2. Measures should be simple and easy to use - Measures should be such that stakeholders and employees can understand and follow through with minimal complications.

3. A performance measurement system should establish a link between operational processes and strategic goals The purpose of each operation in helping the SME to achieve its strategic goals must be clear. 
4. A performance measurement system should provide timeous and accurate feedback - Deviations from the strategic goal of the SME must be identified in time. Additionally, changing dynamics in SME's operating environment must be tracked by the system.

5. It must have the ability to challenge the strategy and question the status quo - A dynamic performance measurement system must be able to question the why and how of the SME's strategic goals.

6. It must be reflective of the business process and encompass the interests of all stakeholders crucial to the success of the SME such as suppliers, customers and employees.

7. Performance measurement should focus on specific deliverables with a clear emphasis on improvement of business processes.

\section{Overview of applied techniques}

In this chapter, overview of applied techniques for situations similar to research project conditions is given. For given research, it is necessary to explore how other researchers measure a company performance in case where they want to present the impact of different dimensions (innovation, quality, digitization, etc.) on it. This paper pay attention on papers that cover central aspects:

1. Papers where individual measures of performance were measured (without formal performance measurement system),

2. Papers where the impact of different internal and external company variables on organisational performance was measured.

Around 50 papers from most used scientific databases (Scopus, ScienceDirect, Google Scholar) were analysed. Only papers that pay attention to above mentioned central aspects was considered. Table 1 represents the papers that will be further analysed. Out of 50 papers, 12 of them have explicitly explained method that was used for performance measurement.

\begin{tabular}{|c|c|}
\hline Authors and research purpose & Organisational performance measure \\
\hline $\begin{array}{l}\text { Authors: S. Li, B. Ragu-Nathan, T. S. Ragu- } \\
\text { Nathan, and S. Subba Rao (2006) [29] } \\
\text { Purpose: to measure the impact of supply chain } \\
\text { management practices on competitive advantage } \\
\text { and organizational performance }\end{array}$ & $\begin{array}{l}\text { Measured market performance and financial performance on a } \\
\text { five-point scale. Dimensions (market share, return on investment, } \\
\text { the growth of market share, the growth of sales, growth in return } \\
\text { on investment, profit margin on sales and overall competitive } \\
\text { position) were measured by survey on a five-point Likert scales. }\end{array}$ \\
\hline $\begin{array}{l}\text { Authors: S. C. L. Koh, M. Demirbag, E. } \\
\text { Bayraktar, E. Tatoglu, and S. Zaim (2007) [30] } \\
\text { Purpose: To measure supply chain } \\
\text { management practices on performance of SMEs }\end{array}$ & $\begin{array}{l}\text { Authors measured level of organisational performance (PERF) } \\
\text { based on managers' perceptions of how the organization } \\
\text { performed on multiple indicators of organizational performance } \\
\text { relative to its rivals based on a five-point scale, ranging from } \\
\text { "much worse than rivals" through "much better than rivals". The } \\
\text { PERF construct was composed of financial, non-financial and } \\
\text { efficiency indicators which include: revenue growth over the last } \\
\text { three years, net profits, profit to revenue ratio, return on assets, } \\
\text { investment in R\&D aimed at new innovations, capacity to } \\
\text { develop a unique competitive profile, new product/service } \\
\text { development, market development and market orientation, cost } \\
\text { per adjusted discharge, reject rate and waste and return on assets. }\end{array}$ \\
\hline $\begin{array}{l}\text { Authors: I. M. Salim and M. Sulaiman (2011) } \\
\text { [31] } \\
\text { Purpose: To measure organizational learning } \\
\text { and innovation and their impact on performance }\end{array}$ & $\begin{array}{l}\text { Examined organisational performance using two aspects: } \\
\text { financial performance and market performance. Financial } \\
\text { performance refers to the extent to which the organization } \\
\text { performs in relative profitability, return on investment, and total } \\
\text { sales growth. Market performance refers to the extent to which } \\
\text { the organization performs in market share, profit ratio, and } \\
\text { customer satisfaction. They used questionnaire that utilizes a five- } \\
\text { point Likert scale. }\end{array}$ \\
\hline $\begin{array}{l}\text { Authors: C. Valmohammadi (2011) [32] } \\
\text { Purpose: to measure the impact of TQM } \\
\text { implementation on the organizational } \\
\text { performance }\end{array}$ & $\begin{array}{l}\text { Organizational performance on scale from } 1 \text { to } 7 \text {, by respondents } \\
\text { from the company. It was covered by five constructs: customer } \\
\text { satisfaction, employee morale, market share, sales growth and } \\
\text { profitability. Recorded by survey. }\end{array}$ \\
\hline $\begin{array}{l}\text { Authors: H. Frank and A. Kessler (2012) [33] } \\
\text { Purpose: To measure the impact of learning } \\
\text { orientation of SME on firm performance }\end{array}$ & $\begin{array}{l}\text { Firm performance in their model consists of five dimensions: (1) } \\
\text { revenues, (2) number of employees, (3) market share, (4) share of } \\
\text { regular customers, and (5) success with new products/processes. } \\
\text { Respondents were asked to rate the development of the five }\end{array}$ \\
\hline
\end{tabular}




\begin{tabular}{|c|c|}
\hline & $\begin{array}{l}\text { dimensions over the last (full) three years preceding the survey. } \\
\text { The indicators of success were put into relation with major } \\
\text { competitors, using } 7 \text { - point scales ( } 1 \text { - far lower than competitors; } \\
7 \text { - far higher than competitors). }\end{array}$ \\
\hline $\begin{array}{l}\text { Authors: L. Zhao, B. Huo, L. Sun, and X. Zhao } \\
\text { (2013) [34] } \\
\text { Purpose: Measure the impact of supply chain } \\
\text { risk on supply chain integration and company } \\
\text { performance }\end{array}$ & $\begin{array}{l}\text { They separate performance on three types: operational } \\
\text { performance (schedule attainment, competitive performance and } \\
\text { customer satisfaction. Competitive performance was measured } \\
\text { using } 12 \text { key aspects by asking the plant manager to rate how well } \\
\text { the plant performs compared to its competition in the industry. }\end{array}$ \\
\hline $\begin{array}{l}\text { Authors: S. Rozenes, I. Kukliansky, G. Vitner } \\
\text { (2014) [35] } \\
\text { Purpose: Measure an impact of enterprise } \\
\text { resource planning implementation success on } \\
\text { organisational performance }\end{array}$ & $\begin{array}{l}\text { Organizational performance assessment was realized through } \\
\text { three elements: financial improvement, operations improvement } \\
\text { and customer's satisfaction improvement. It was measured by } \\
\text { responses from the questionnaire on a 1-6 scale. }\end{array}$ \\
\hline $\begin{array}{l}\text { Authors: N. Azad and F. Ahmadi (2015) [36] } \\
\text { Purpose: Measurement of customer } \\
\text { relationship management process and its impact } \\
\text { on performance }\end{array}$ & $\begin{array}{l}\text { Used perceptual performance and economic performance } \\
\text { (objective) - ROA (return on assets). Perceptual performance was } \\
\text { measured by survey using seven-point Likert scale and economic } \\
\text { performance from company reports and secondary sources. }\end{array}$ \\
\hline $\begin{array}{l}\text { Authors: S. C. Lonial and R. E. Carter (2015) } \\
\text { [37] } \\
\text { Purpose: to measure the impact of } \\
\text { organizational orientations on organisational } \\
\text { performance }\end{array}$ & $\begin{array}{l}\text { Used survey with three dimensions related to firm performance: } \\
\text { financial performance, market performance and quality } \\
\text { performance. They used a 5-point Likert-type to rate the items. }\end{array}$ \\
\hline $\begin{array}{l}\text { Authors: Bakotić (2016) [38] } \\
\text { Purpose: To measure relationship between job } \\
\text { satisfaction and organisational performance }\end{array}$ & $\begin{array}{l}\text { Author analysed organisational performance through financial } \\
\text { indicators: total asset turnover, current asset turnover, revenues } \\
\text { over expenses ratio, ROA, return on equity (ROE), ROCE } \\
\text { (Return on Capital Employed), revenue per employee, earnings } \\
\text { before taxes per employee, labour costs per employee, index } \\
\text { BEX. The data about organisational performance was collected } \\
\text { through questionnaire which contained questions about the } \\
\text { financial information of each company over a two-year period. }\end{array}$ \\
\hline $\begin{array}{l}\text { Authors: E. H. Al Khajeh (2018) [39] } \\
\text { Purpose: to measure impact of leadership styles } \\
\text { on organizational performance }\end{array}$ & $\begin{array}{l}\text { Respondent's perception of their organization's performance in } \\
\text { comparison to their competitors on a five-point scale. Measured } \\
\text { by survey }\end{array}$ \\
\hline $\begin{array}{l}\text { Authors: D. Yu, H. Xiao, and Q. Bo (2018) } \\
\text { [40] } \\
\text { Purpose: to define dimensions of } \\
\text { organizational character and its impacts on } \\
\text { organizational performance }\end{array}$ & $\begin{array}{l}\text { Used two items correspondingly to measure organizational } \\
\text { performance: "the current financial performance of my } \\
\text { organization is very high compared with other organizations in } \\
\text { the same industry" and "my organization has great potential for } \\
\text { development." They used a 5-point Likert-type to rate the items. }\end{array}$ \\
\hline
\end{tabular}

Table 1. Overview of measurement performance methods

\section{Conclusion}

The purpose of this paper was to give overview of methods used to measure SMEs' organisational performance, particularly on articles that cover central aspects: papers where individual measures of performance were measured (without formal performance measurement system) and papers where the impact of different internal and external company variables on organisational performance was measured.

Most of the papers (analysed in chapter 3) that wanted to measure impact of internal and/or external variables (information system, organisation, supply chain, quality, strategy etc.) on organisational performance have used a survey method for gathering the data. Almost all of them have used both financial and non-financial performance data (strategic/operational performance). Their own perception of certain factors comparing to their rivals were measured. All those obtained performance results are based on subjective opinion of the surveyed participants. Also, most of the papers have used exploratory and confirmatory factor analysis to identify the relationships between measured variables and to test whether measures of a construct are consistent with a researcher's understanding of the nature of that construct. The 
use of subjective indicators could have implications for the dimensional structure found. Second, financial construct that use objective data, should be introduced. The regression analysis between objective and subjective performance measures should suggest this dimensional structure may hold for data collected with objective indicators.

Limitation of this paper is a relative low quantity of narrowed papers that precludes the generalisation of the finding.

Based on the collected data, next step in research would be design, implementation and validation of framework/methodology for performance measurement in small and medium enterprises. Future research could conduct a panel study with a different group of stakeholders and in a different geographical area to determine the robustness, reliability and generalizability of the results.

\section{References}

[1] Sousa, S., \& Aspinwall, E. (2010). Development of a performance measurement framework for SMEs. Total Quality Management and Business Excellence, 21(5), 475-501. https://doi.org/10.1080/14783363.2010.481510

[2] Bilas, V., \& Franc, S. (2010). The role of performance measurement systems on globalized markets. DAAAM International Scientific Book, 313-321.

[3] Muller, P., Mattes, A., Klitou, D., Lonkeu, O.-K., Ramada, P., Ruiz, F., ... Streigertahl, L. (2018). Annual Report on European SMEs, The 10 th anniversary of the Small Business Act. https://doi.org/10.2873/248745

[4] Ensari, M. Ş., \& Karabay, M. E. (2014). What Helps to Make SMEs Successful in Global Markets? Procedia - Social and Behavioral Sciences, 150, 192-201. https://doi.org/10.1016/J.SBSPRO.2014.09.030

[5] Todericiu, R., \& Stăniţ, A. (2015). Intellectual Capital - The Key for Sustainable Competitive Advantage for the SME's Sector. Procedia Economics and Finance, 27, 676-681. https://doi.org/10.1016/S2212-5671(15)01048-5

[6] Gonçalves, J. M., Ferreira, F. A. F., Ferreira, J. J. M., \& Farinha, L. M. C. (2019). A multiple criteria group decisionmaking approach for the assessment of small and medium-sized enterprise competitiveness. Management Decision, 57(2), 480-500. https://doi.org/10.1108/MD-02-2018-0203

[7] Cocca, P., \& Alberti, M. (2010). A framework to assess performance measurement systems in SMEs. International Journal of Productivity and Performance Management, 59(2), $186-200$. https://doi.org/10.1108/17410401011014258

[8] Garengo, P., Biazzo, S., \& Bititci, U. S. (2005). Performance measurement systems in SMEs: A review for a research agenda. International Journal of Management Reviews, 7(1), 25-47. https://doi.org/10.1111/j.14682370.2005.00105.x

[9] Hudson, M., Smart, A., \& Bourne, M. (2001). Theory and practice in SME performance measurement systems. International Journal of Operations \& Production Management, 8(8), 144-3577. Retrieved from http://www.em

[10] Olaitan, O., \& Flowerday, S. (2017). Critical success factors in introducing performance measurement metrics for small and medium-sized enterprises (SMEs). International Journal of Education Economics and Development, 8(2/3), 144. https://doi.org/10.1504/ijeed.2017.10007358

[11] User guide to the SME Definition. (n.d.). https://doi.org/10.2873/782201

[12] Robbins, S. P. (1990). Organization theory : structure, design, and applications. Prentice Hall.

[13] Jenatabadi, H. S. (2015). An Overview of Organizational Performance Index: Definitions and Measurements The electrochemical capacitive behavior of polymer-based nanocomposites View project An Overview of Organizational Performance Index: Definitions and Measurements, (May), 1-10. https://doi.org/10.13140/RG.2.1.4298.3849

[14] Georgopoulos, B. S., \& Tannenbaum, A. S. (1957). A Study of Organizational Effectiveness. American Sociological Review, 22(5), 534. https://doi.org/10.2307/2089477

[15] Cherrington, D. J. (1994). Organizational behavior : the management of individual and organizational performance (2nd ed.). Boston: Allyn and Bacon. Retrieved from https://www.worldcat.org/title/organizational-behavior-themanagement-of-individual-and-organizational-performance/oclc/968953249?referer=di\&ht=edition

[16] Saunila, M. (2016). Performance measurement approach for innovation capability in SMEs. International Journal of Productivity and Performance Management, 65(2), 162-176. https://doi.org/10.1108/IJPPM-08-2014-0123

[17] Measurement of Intangible Success Factors: Case Studies on the Design, Implementation and Use of Measures Tampere University of Technology. (n.d.). Retrieved September 23, 2019, from https://tutcris.tut.fi/portal/en/publications/measurement-of-intangible-success-factors-case-studies-on-the-designimplementation-and-use-of-measures(f36eb07e-2726-4f4f-a1bd-f20c20e00862)/export.html

[18] Sink, D. S. (1985). Productivity management : planning, measurement and evaluation, control, and improvement. Wiley.

[19] De Toni, A., \& Tonchia, S. (2001). Performance measurement systems - Models, characteristics and measures. International Journal of Operations \& Production Management, 21(1/2), 46-71. https://doi.org/10.1108/01443570110358459

[20] Neely, A., Mills, J., Platts, K., Richards, H., Gregory, M., Bourne, M., \& Kennerley, M. (2000). Performance measurement system design: developing and testing a process-based approach. International Journal of Operations \& Production Management, 20(10), 1119-1145. https://doi.org/10.1108/01443570010343708

[21] Kaplan, R. S., \& Norton, D. P. (n.d.). The balanced scorecard : translating strategy into action.

[22] Neely, A. D. (Andy D. ., Adams, C., \& Kennerley, M. (2002). The performance prism : the scorecard for measuring and managing business success. Financial Times/Prentice Hall. 
[23] Liang, T. P., You, J. J., \& Liu, C. C. (2010). A resource-based perspective on information technology and firm performance: A meta analysis. Industrial Management and Data Systems, 110(8), 1138-1158. https://doi.org/10.1108/02635571011077807

[24] Santos, J. B., \& Brito, L. A. L. (2012). Toward a subjective measurement model for firm performance. BAR Brazilian Administration Review, 9(SPL. ISS), 95-117. https://doi.org/10.1590/S1807-76922012000500007

[25] Tarute, A., \& Gatautis, R. (2014). ICT Impact on SMEs Performance. Procedia - Social and Behavioral Sciences, 110, 1218-1225. https://doi.org/10.1016/j.sbspro.2013.12.968

[26] Eccles, R. G. (n.d.). The performance measurement manifesto. Harvard business review, 69(1), 131-7. Retrieved from http://www.ncbi.nlm.nih.gov/pubmed/10109469

[27] Bititci, U., Garengo, P., Dörfler, V., \& Nudurupati, S. (2012). Performance Measurement: Challenges for Tomorrow. International Journal of Management Reviews, 14(3), 305-327. https://doi.org/10.1111/j.1468-2370.2011.00318.x

[28] Tenhunen, J., Ukko, J., Markus, T., \& Rantanen, H. (2002). Designing a performance measurement system: a case study in the telecom business. Retrieved from https:/www.semanticscholar.org/paper/designing-a-performancemeasurement-system\%3A-A-CASE-Tenhunen-Ukko/fe5fdde69d2d59e9213b786881800b1f71aa42d5

[29] Li, S., Ragu-Nathan, B., Ragu-Nathan, T. S., \& Subba Rao, S. (2006). The impact of supply chain management practices on competitive advantage and organizational performance. Omega, 34(2), $107-124$. https://doi.org/10.1016/j.omega.2004.08.002

[30] Koh, S. C. L., Demirbag, M., Bayraktar, E., Tatoglu, E., \& Zaim, S. (2007). The impact of supply chain management practices on performance of SMEs. Industrial Management and Data Systems, 107(1), $103-124$. https://doi.org/10.1108/02635570710719089

[31] Salim, I. M., \& Sulaiman, M. (2011). Organizational Learning, Innovation and Performance: A Study of Malaysian Small and Medium Sized Enterprises. International Journal of Business and Management, 6(12), 118-125. https://doi.org/10.5539/ijbm.v6n12p118

[32] Valmohammadi, C. (2011). The impact of TQM implementation on the organizational performance of Iranian manufacturing SMEs. TQM Journal, 23(5), 496-509. https://doi.org/10.1108/17542731111157608

[33] Frank, H., \& Kessler, A. (2012). Learning Orientation of SMEs and Its Impact on Firm Performance. Journal of Marketing Development and Competitiveness, 6(3), 29-42. Retrieved from http://www.nabusinesspress.com/JMDC/frank_abstract.html

[34] Zhao, L., Huo, B., Sun, L., \& Zhao, X. (2013). The impact of supply chain risk on supply chain integration and company performance: a global investigation. Supply Chain Management: An International Journal, 18(2), 115131. https://doi.org/10.1108/13598541311318773

[35] Rozenes, S., Kukliansky, I., \& Vitner, G. (2014). The impact of an enterprise resource planning implementation success on organisational performance. International Journal of Data Analysis Techniques and Strategies, 6(4), 348361. https://doi.org/10.1504/IJDATS.2014.066597

[36] Azad, N., \& Ahmadi, F. (2015). The customer relationship management process: Its measurement and impact on performance. Uncertain Supply Chain Management, 3(1), 43-50. https://doi.org/10.5267/j.uscm.2014.9.002

[37] Lonial, S. C., \& Carter, R. E. (2015). The impact of organizational orientations on medium and small firm performance: A resource-based perspective. Journal of Small Business Management, 53(1), 94-113. https://doi.org/10.1111/jsbm.12054

[38] Bakotić, D. (2016). Relationship between job satisfaction and organisational performance. Economic ResearchEkonomska Istraživanja, 29(1), 118-130. https://doi.org/10.1080/1331677X.2016.1163946

[39] Khajeh, E. H. Al. (2018). Impact of Leadership Styles on Organizational Performance. Journal of Human Resources Management Research, 2018. https://doi.org/10.5171/2018.687849

[40] Yu, D., Xiao, H., \& Bo, Q. (2018). The Dimensions of Organizational Character and Its Impacts on Organizational Performance in Chinese Context. Frontiers in psychology, 9, 1049. https://doi.org/10.3389/fpsyg.2018.01049 